\title{
Relevansi Pemikiran Fazlur Rahman Terhadap Pendidikan Modern di Indonesia
}

\author{
UMMU MAWADDAH* \\ SITI KAROMAH** \\ Universitas Islam Negeri Sunan Kalijaga Yogyakarta \\ Jl. Marsda Adisucipto Yogyakarta Kode Pos 55281 \\ Email: mumtazz.mawaddah@gmail.com \\ $* *$ \\ Universitas Islam Negeri Sunan Kalijaga Yogyakarta \\ Jl. Marsda Adisucipto Yogyakarta Kode Pos 55281 \\ Email: skaromah411@gmail.com
}

\begin{abstract}
Fazlur Rahman is a modern Islamic thinker that combines general knowledge and religious knowledge. It is with this combination of knowledge that you can use strong privacy in religion while having sufficient general knowledge. Thus he will have a balanced knowledge. Take a look at the existing education in Indonesia which also has the same problem with what is related to Fazlur Rahman in Pakistan and the author of education in Indonesia relevant to Fazlur Rahman's thinking. With research library method of authors do an analysis of the relevance. From the analysis, it can be concluded that Fazlur Rahman is relevant to education in Indonesia, Islamic Education, Educational Objectives, Educate Participants, Educators, Educational Methods.
\end{abstract}

Keywords: Relevance, Thought, Education, Fazlur Rahman

\begin{abstract}
Abstrak: Fazlur Rahman merupakan Pemikir Islam modern yang memadukan antara pengetahuan umum dan pengetahuan agama. Dengan perpaduan pengetahuan inilah diharapkan dapat menghasilkan pribadi yang kuat dalam beragama sekaligus memiliki pengetahuan umum yang memadai. Dengan demikian ia akan memiliki pengetahuan yang seimbang. Melihat pendidikan yang ada di Indonesia yang juga memiliki problem yang sama dengan apa yang dihadapi Fazlur Rahman sewaktu di Pakistan maka penulis maka apakah pendidikan di Indonesia relevan dengan pemikiran Fazlur Rahman. Dengan metode library research penulis melakukan analisis terhadap relevansi tersebut. Dari hasil analisis yang dilakukan, diperoleh kesimpulan bahwa pemikiran Fazlur Rahman relevan dengan pendidikan di Indonesia dilihat dari segi dasar pendidikan, pengertian pendidikan Islam, tujuan pendidikan, peserta didik, pendidik, metode pendidikan.
\end{abstract}

Kata kunci: Relevansi, Pemikiran, Pendidikan, Fazlur Rahman 


\section{PENDAHULUAN}

Dunia Islam mengalami berbagai macam kemunduran, terutama semenjak Baghdad jatuh ke tangan Hulagu Khan. Tidak saja masalah politik yang kacau, kondisi ekonomi bahkan intelektual kaum muslim pun semakin melemah. Pada kenyataannya, kita akan melihat betapa minat melakukan riset dan semangat belajar kaum muslim benar-benar hampir padam, berbanding terbalik dengan Barat yang semakin berjaya dengan kemajuan IPTEK mereka. Mereka bahkan mampu mengembangkan pengetahuannya sekaligus menjajah secara perlahan kaum muslim hingga terhambat untuk maju.

Melihat kondisi yang begitu mengerikan ini, Fazlur Rahman tergerak hatinya untuk melakukan pembaruanpembaruan, terutama di bidang pendidikan Islam. Fazlur Rahman adalah seorang pemikir dan penulis ulung yang berhaluan modern. Dengan metode $a$ double movementnya, Rahman berharap munculnya pribadi-pribadi muslim yang tangguh, yang tidak saja cakap dalam ilmu-ilmu umum, tetapi juga cakap dalam ilmu agama Islam serta mengamalkannya. Hanya saja, keinginan untuk memajukan Pakistan sebagai tanah kelahirannya kemudian mengundang banyak tantangan dari kaum tradisional sehingga ia memutuskan untuk hijrah. Ia adalah orang luar biasa yang lahir dari Islam dan untuk Islam. Berbagai pemikirannya dirancang untuk memajukan pendidikan Islam supaya tidak tertinggal jauh dari Barat. Pemikiran-pemikiran ia yang hebat tersebut kemudian penulis relevansikan dengan pendidikan di Indonesia masa kini agar dapat diambil sisi-sisi positif sekaligus untuk mengabadikan perannya yang begitu luar biasa dalam memajukan
Islam. Sebagaimana kita kita ketahui, Indonesia memiliki problem yang sama dengan permasalahan yang pernah dihadapi oleh Rahman sewaktu di Pakistan. Melalui tulisan ini, penulis mencoba mengambil titik temu antara pemikiran Fazlur Rahman dalam mengatasi problematika di negaranya dengan problematika yang terjadi di Indonesia.

Selanjutnya, tulisan ini membahas beberapa hal terkait: 1) biografi Fazlur Rahman, 2) Latar belakang pendidikan Fazlur Rahman, dan 3) Relevansi pemikiran Fazlur Rahman terhadap pendidikan modern di Indonesia.

\section{KAJIAN PUSTAKA}

Khotimah dalam Jurnal Ushuluddin dengan judul "Pemikiran Fazlur Rahman Tentang Pendidikan Islam" mengambil kesimpulan bahwa hal yang menarik dari ide fazlur rahman adalah model pendidikan Islam melalui kurikulumnya mengarah pada pendidikan berkarakter Islami dan integrasi ilmu dilihat dari pola pikir Fazlur Rahman tentang Neomodernisme. Fazlur Rahman juga menyebutkan bahwa pada substansinya pendidikan Islam itu bertujuan untuk memperbaiki moral manusia (Khotimah, 2014: 251-252).

Mustafa dalam Jurnal Pendidikan Islam Iqra' dengan judul "Pemikiran Pendidikan Fazlur Rahman" mengambil kesimpulan bahwa gagasan dan pemikiran Fazlur Rahman didasarkan pada upaya mengatasi empat problem yang dihadapi umat yaitu problem ideologis, problem dualism dalam sistem pendidikan, problem bahasa, dan problem metode pembelajaran. Selain itu konsep pendidikan Fazlur Rahman juga 
dipengaruhi oleh sikap dan kepribadiannya sebagai seorang modernis serta pemikirannya sangat terkait erat dengan upaya memecahkan masalah yang dihadapi umat (Mustafa, 2018: 13-14)

Muhammad Fahmi dalam Jurnal Pendidikan Agama Islam dengan judul "Pendidikan Islam Perspektif Fazlur Rahman" mengatakan bahwa ide-ide Rahman mengenai pendidikan Islam termasuk dalam kategori kontekstual. Ini menunjukkan bahwa dalam mengemukakan ide-idenya, Rahman mendasarkannya pada pengalaman empirik dan pengamatan yang realistis. Sehingga ide-idenya dapat diterapkan dalam menganalisis pendidikan Islam kontemporer. Akan tetapi perlu diberikan kritis-transformatif bagi ide-ide Rahman sebelum diterapkan dalam konteks kekinian karena konteks sosial Rahman berbeda dengan konteks umat Islam pada masa sekarang (Muhammad Fahmi, 2016: 81).

Dari kajian pustaka yang penulis lakukan, penulis belum menemukan judul yang sama dengan penelitian ini, sehingga penelitian yang berjudul Relevansi Pemikiran Fazlur Rahman Terhadap Pendidikan Modern di Indonesia layak untuk dilakukan.

\section{METODE PENELITIAN}

Penelitian ini adalah penelitian deskriptif kualitatif, yaitu metode penelitian yang bertujuan untuk menggambarkan secara utuh dan mendalam tentang realitas sosial dan berbagai fenomena yang terjadi di masyarakat (Wina Sanjaya, 2013: 47). Penelitian ini merupakan penelitian kepustakaan atau literatur (library research) yang memfokuskan kajiannya pada buku-buku berbahasa Indonesia maupun asing. Penelitian kepustakaan adalah jenis penelitian yang berusaha menghimpun data penelitian dari khazanah literatur dan menjadikan dunia teks sebagai bahan utama analisisnya (Winarno Surakhmad, 1992: 139). Sumber-sumber lain yang relevan juga dapat menunjang dan memperkaya data yang diperlukan. Sumber data penelitian ini dihasilkan melalui dua sumber, yaitu sumber primer dan sekunder. Sumber primer penelitian ini menggunakan bukubuku karya Fazlur Rahman. Adapun sumber sekundernya menggunakan bukubuku dan jurnal yang membahas pemikiran Fazlur Rahman.

Pengumpulan data pada penelitian ini menggunakan metode dokumentasi, yakni teknik pengumpulan data dengan jalan menganalisis data dokumen, yaitu berupa sumber-sumber data dari beberapa literatur yang memiliki relevansi dengan tema penelitian (Suharsimi Arikunto, 1998: 236). Dokumentasi di sini dapat berupa buku, jurnal, surat kabar, majalah, ataupun internet yang relevan dengan penelitian ini. Dokumen juga bisa berupa gambar, tulisan, atau karya-karya monumental seseorang, misalnya catatan harian, sejarah kehidupan, biografi, peraturan, maupun kebijakan. (Sugiyono, 2013: 396).

\section{BIOGRAFI FAZLUR RAHMAN}

Fazlur Rahman dilahirkan di Hazara (daerah India Inggris) yang sekarang Pakistan pada tanggal 21 September 1919. Pendidikannya dimulai dari lingkungan keluarga yang taat beragama. Ayahnya, Maulana Syihabuddin adalah seorang alim terkenal lulusan Darul Ulum Doeband. Ayahnya adalah seorang kyai yang mengajar di madrasah tradisional paling bergengsi di anak benua Indo-Pakistan 
(Ikhtiono, 2014: 32). Ayahnya memperhatikan Rahman dalam hal mengaji dan menghafal al-Qur'an sehingga pada usia sepuluh tahun, Rahman telah hafal al-Qur'an seluruhnya (Nata, 2013: 315). Selain itu, ia juga menerima ilmu hadis dan ilmu syariah lainnya. Pendidikan dalam keluarganya benarbenar telah efektif dalam membentuk watak dan kepribadiannya untuk dapat menghadapi kehidupan nyata.

Beberapa faktor yang mempengaruhi pemikiran kegamaan Fazlur Rahman adalah ketekunan ayahnya dalam mengajarkan agama dengan disiplin tinggi sehingga dia mampu menghadapi berbagai macam peradaban dan tantangan di alam modern, di samping pengajaran ibunya terutama tentang kejujuran, kasih sayang, serta kecintaan sepenuh hati darinya (Rahman, 1990: 227). Kondisi keluarga yang demikian sangat kondusif bagi Fazlur Rahman untuk mengenali ilmu-ilmu dasar tradisional, juga untuk kelanjutan karier pendidikannya.

Hal lain yang mempengaruhi pemikiran keagamaan Rahman adalah bahwa dia dididik dalam sebuah keluarga dengan tradisi madzhab Hanafi, sebuah madzhab Sunni yang lebih banyak menggunakan rasio (ra'yu) dibandingkan dengan madzhab sunni lainnya. Selain itu, India ketika itu telah berkembang pemikiran yang agak liberal, seperti pemikiran Syah waliullah, Sayid Ahmad Khan, Sir Sayid, Amir Ali, dan Muhammad Iqbal (Nata, 2013: 315-316). Secara khusus, ia lebih cenderung mengikuti pemikiran Syah Waliullah dan Muhammad Iqbal (Ikhtiono, 2014: 33).
RIWAYAT PENDIDIKAN FAZLUR RAHMAN

Meskipun Fazlur Rahman tidak belajar di Darul Ulum (tempat ayahnya belajar waktu itu), namun ia menguasai kurikulum Darse Nazami yang ditawarkan lembaga tersebut dalam kajian privat dengan ayahnya. Ini melengkapi latar belakangnya dalam memahami Islam tradisional dengan perhatian khusus pada Fikih, Ilmu Kalam, Hadis, Tafsir, Mantiq, dan Filsafat (Ikhtiono, 2010: 33).

Setelah

memperoleh penggemblengan dasar dari ayahnya, sekolah modern Fazlur Rahman dimulai dari Lahore pada 1933. Selesai dari pendidikan menengah ini, dia meneruskan ke Universitas Punjab, dan lulus menyandang gelar B.A. pada 1940 dalam spesialisasi bahasa Arab. Dua tahun kemudian, dia memperoleh gelar magister dalam bidang yang sama dari perguruan tinggi yang sama (Sibawaihi, 2010: 7).

Merasa tidak puas dengan pendidikan di tanah airnya, pada tahun 1946 Fazlur Rahman berangkat ke Oxford University, Inggris untuk melanjutkan studi doktoralnya. Rahman menulis desertasi mengenai psikologi Ibnu Sina di bawah bimbingan Prof. Simon Van Den Bergh yang kemudian diterbitkan dengan judul Avicenna's Psychologi.

Fazlur Rahman giat mempelajari bahasa-bahasa Barat sehingga menguasai banyak bahasa. Paling tidak, ia menguasai bahasa Latin, Yunani, Inggris, Perancis, Jerman, Turki, Persia, Arab, dan Urdu. Karena banyaknya bahasa yang dikuasai, ia juga mengajar beberapa saat di Durham University, Inggris. Selanjutnya, dia pindah dari Inggris untuk menjadi Associate Professor pada bidang studi 
Islam di Institute of Islamic Studies McGill University, Kanada (Nata, 2013: 316-317).

Setelah tiga tahun di Kanada, Fazlur Rahman kembali ke tanah air dan memulai proyek paling ambisius dalam hidupnya. Ia diangkat sebagai direktur pada Institute of Islamic Research dan memprakarsai penerbitan Journal of Islamic Studies yang hingga kini masih terbit secara berkala dalam taraf internasional. Untuk memajukan lembaga riset ini, Rahman menerapkan strategi ganda, yaitu memadukan pengetahuan umum dan agama sehingga terintegrasi menjadi satu kesatuan yang utuh. Harapannya adalah membentuk pribadi yang kuat beragama sekaligus memiliki kecakapan dalam bidang-bidang umum dan modern. Di samping menjadi direktur pada lembaga riset tersebut, Fazlur Rahman diangkat sebagai direktur pada Advisory Council of Islamic Ideology pemerintah Pakistan pada tahun 1964 (Ikhtiono, 2010: 35).

Usaha Fazlur Rahman ternyata tidak begitu berkenan di hati ulama tradisional. Alasannya, jabatan direktur lembaga tersebut sepantasnya menjadi hak eksklusif dan istimewa para ulama yang terdidik secara tradisional. Rahman dianggap sebagai kelompok modernis yang telah terkontaminasi dengan pikiranpikiran Barat. Dengan demikian, selama di bawah kepemimpinan Rahman, lembaga riset ini selalu mengalami tantangan dari kaum tradisional dan fundamental. Tantangan ini diperparah dengan ketegangan politik antara ulama tradisional dengan pemerintah Ayyub Khan yang dianggap berhaluan modernis. Pada saat-saat itulah Rahman memutuskan untuk meninggalkan negerinya (Sibawaihi, 2010: 9-10).
Fazlur Rahman pun memutuskan hijrah ke Chicago dan menjabat sebagai guru besar dalam kajian Islam dalam segala aspeknya pada Departemen of Near Eastern Languages and Civilization, University Chicago Los Angeles pada tahun 1969. Pada tahun 1986 ia dianugerahi Harold H. Swift Distinguished Service Professor di Chicago. Penghargaan ini disandangnya sampai wafat 26 Juli 1988 (Ikhtiono, 2010: 36-37).

Berdasarkan uraian di atas, kita dapat memahami bahwa Fazlur Rahman merupakan seorang pemikir dan penulis produktif yang memiliki kepedulian tinggi untuk mengatasi problematika umat, terutama yang dihadapi oleh negaranya. Sayangnya, negara di mana ia dilahirkan belum bisa menerima pemikiran yang dianggap radikal dan terkontaminasi pemikiran Barat tersebut. Maka dengan terpaksa, ia meninggalkan tanah airnya dan menetap di Chicago hingga wafat. Di sana, pemikiran dan kontribusi ia sangat dihargai. Kondisi seperti inilah yang sering kita jumpai di sekitar kita, di mana para tokoh atau ilmuwan terabaikan sehingga mereka memilih hijrah ke negara yang mau menerimanya. Tak jarang, prestasiprestasi mereka kemudian membumbung tinggi hingga tercium ke negara-negara tetangga bahkan kalangan internasional.

\section{PEMIKIRAN PENDIDIKAN FAZLUR RAHMAN DAN RELEVANSINYA}

Fazlur Rahman memiliki beberapa konsep pemikiran pendidikan yang akan diuraikan beserta relevansinya sebagai berikut:

\section{Dasar Pendidikan}

Menurut Fazlur Rahman, sumber nilai yang menjadi dasar pendidikan adalah al-Qur'an. Ajaran al-Qur'an 
adalah moral yang diperuntukkan bagi tindakan manusia yang kreatif. Kepentingan sentral al-Qur'an adalah pada manusia dan perbaikannya. AlQur'an mengandung nilai-nilai fundamental yang dapat dijadikan dasar dalam pelaksanaan pendidikan Islam, seperti tauhid, kemanusiaan, kesatuan umat, dan rahmatan lil 'alamin (Rahman, 1994: 39-40).

Dasar pendidikan Islam identik dengan dasar ajaran Islam itu sendiri. Keduanya berasal dari sumber yang sama, yaitu al-Qur'an dan hadis. Dasar itu kemudian dikembangkan dalam pemahaman ulama dan sebagainya, sehingga kita mengenal adanya ijtihad, 'urf, masalih al-mursalah, dan sebagainya.

Dasar pendidikan yang dikemukakan Fazlur Rahman sejalan dengan dasar pendidikan di Indonesia. Pendidikan di Indonesia harus berdasarkan pada falsafah hidup bangsa Indonesia, yakni Pancasila. Pancasila terdiri dari lima sila yang berbunyi, "(1) Ketuhanan Yang Maha Esa, (2) Kemanusiaan yang adil dan beradab, (3) Persatuan Indonesia, (4) Kerakyatan yang dipimpin oleh hikmat kebijaksanaan dalam permusyawaratan perwakilan, serta (5) Keadilan sosial bagi seluruh rakyat Indonesia."

Jika kita cermati, kelima sila yang terkandung dalam Pancasila merupakan penjabaran nilai-nilai alQur'an, seperti tauhid, kemanusiaan, kesatuan umat, musyawarah, dan keadilan. Nilai-nilai yang terkandung dalam Pancasila tersebut dapat dijadikan sebagai dasar pelaksanaan pendidikan di Indonesia secara universal.

2. Pengertian Pendidikan Islam

Pendidikan Islam menurut Rahman mencakup dua pengertian besar, pertama yaitu pendidikan yang diselenggarakan di negara-negara Islam, sementara yang kedua dapat dipahami sebagai proses untuk menghasilkan manusia integratif yang padanya terkumpul sifat-sifat kritis, dinamis, inovatif, dan sebagainya (Rahman, 1982: 151-162).

Adapun definisi pendidikan yang tercantum dalam undang undang Sisdiknas, yaitu "Pendidikan adalah usaha sadar dan terencana untuk mewujudkan suasana belajar dan proses pembelajaran agar peserta didik secara aktif mengembangkan potensi dirinya untuk memiliki kekuatan spiritual keagamaan, pengendalian diri, kepribadian, kecerdasan, akhlak mulia, serta keterampilan yang diperlukan dirinya, masyarakat, bangsa dan negara" (UU Sisdiknas No. 20 Tahun 2003, 2012: 2-3).

Pendidikan merupakan proses internalisasi pengetahuan dan nilai kepada peserta didik melalui pengajaran, bimbingan, pembiasaan, pengawasan, dan pengembangan potensi agar tercipta pribadi yang agamis, cerdas, terampil dan berakhlak mulia. Dengan sifat ini, peserta didik dapat mengikuti perkembangan zaman serta dapat memfilternya. Gagasan Rahman mengenai definisi pendidikan Islam dipandang relevan dengan definisi pendidikan di Indonesia, baik untuk pendidikan Islam maupun pendidikan secara umum, karena pada dasarnya output yang dikehendaki 
memiliki sifat yang sama. Hanya saja, definisi pertama mengenai pendidikan Islam yang dikemukakan Fazlur Rahman kurang relevan dengan Indonesia karena Indonesia sendiri bukan negara Islam, tetapi negara republik.

Selain itu, pendidikan Islam menurut Fazlur Rahman dapat berarti intelektualisme Islam, seperti pendidikan yang diselenggarakan di perguruan tinggi. Hal ini relevan dengan pendidikan Islam yang berarti lembaga, seperti sekolah, madrasah, perguruan tinggi, maupun pesantren.

3. Tujuan Pendidikan

Tujuan pendidikan menurut Fazlur Rahman ada tiga, yaitu:

a. Untuk mengembangkan manusia sedemikian rupa sehingga semua pengetahuan yang diperolehnya akan menjadi organ pada keseluruhan pribadi yang kreatif (Rahman, 1967: 318).

b. Menyelamatkan manusia dari diri sendiri, oleh diri sendiri, dan untuk diri sendiri. Pendidikan adalah bekal terbaik untuk perkembangan setiap individu.

c. Untuk melahirkan ilmuwan yang padanya terintegrasi ilmu-ilmu agama dan ilmu-ilmu umum modern yang ditandai oleh adanya sifat kritis dan kreatif (Rahman, 1967: 316-317).

Selain itu, sebagaimana dikutip oleh Khotimah, Fazlur Rahman menyatakan dengan tegas bahwa tujuan pendidikan Islam adalah untuk menanamkan komitmen-komitmen nilai melalui tarbiyah (pendidikan moral) dan mengkomunikasikan pengetahuan ilmiah melalui ta'lim (pengajaran) (Khotimah, 2014: 249).
Undang-Undang Nomor 20 Tahun 2003 tentang Sisdiknas menyatakan bahwa, "Pendidikan nasional bertujuan untuk mengembangkan potensi peserta didik agar menjadi manusia yang beriman dan bertakwa kepada Tuhan Yang Maha Esa, berakhlak mulia, sehat, berilmu, cakap, kreatif, mandiri, dan menjadi warga negara yang demokratis serta bertanggung jawab."

Dari uraian di atas, dapat penulis simpulkan bahwa tujuan pendidikan menurut Fazlur Rahman relevan dengan tujuan pendidikan Indonesia. Pada dasarnya, pendidikan senantiasa mengarahkan individu menjadi pribadi yang berwawasan imtaq, lebih baik serta seimbang baik dari segi afektif, kognitif, maupun psikomotoriknya. Salah satu cara mewujudkan tujuan tersebut adalah dengan pemberian materi agama dan ilmu-ilmu umum. Selain itu, pendidikan juga bertujuan untuk menghasilkan manusia yang kreatif dan kritis.

Untuk mewujudkan sifat kritis, proses pembelajaran hendaknya berpusat pada peserta didik, karena setiap peserta didik memiliki perbedaan minat (interest), kemampuan (ability), kesenangan (preference), pengalaman (experience) dan cara belajar (learning style). Kegiatan pembelajaran perlu menempatkan peserta didik sebagai subjek belajar dan mendorong peserta didik untuk mengembangkan segenap bakat dan potensinya secara optimal. Adapun untuk mengembangkan sifat kritis peserta didik, diperlukan kemampuan dalam menganalisis pengetahuan kritis. Pengetahuan kritis adalah pengetahuan yang diyakini 
sebagai katalisator dan mobilisator yang mampu membebaskan manusia dari segenap ketidakadilan dan problematika sosial (Assegaf, 2013: 230).

4. Peserta Didik

Menurut Fazlur Rahman, keadaan peserta didik saat ini mengalami permasalahan serius akibat adanya dikotomi, sehingga muncul pribadi yang terpecah-pecah (split personality). Padahal bagi Rahman, ilmu pengetahuan itu pada prinsipnya adalah satu, yaitu berasal dari Allah Swt. (Rahman, Untuk mengatasi hal tersebut, Rahman memiliki alternatif dengan memberikan materi pelajaran secara historis, kritis, dan holistik (Rahman, 1988: 3-11).

Pemberian materi secara historis, kritis, dan holistik sesuai dengan pembelajaran Kurikulum 2013 yang bersifat tematik terpadu. "Pembelajaran Tematik Terpadu dilaksanakan dengan menggunakan prinsip pembelajaran terpadu. Pembelajaran terpadu menggunakan tema sebagai pemersatu kegiatan pembelajaran yang memadukan beberapa mata pelajaran sekaligus dalam satu kali tatap muka, untuk memberikan pengalaman yang bermakna bagi peserta didik. Karena peserta didik dalam memahami berbagai konsep yang mereka pelajari selalu melalui pengalaman langsung dan menghubungkannya dengan konsep lain yang telah dikuasainya."

Pembelajaran tematik terpadu dalam Kurikulum 2013 untuk SD/MI merupakan langkah serius yang diterapkan oleh pemerintah dalam upaya meningkatkan kualitas peserta didik serta menghindarkan dari munculnya split personality seperti yang dikemukakan Fazlur Rahman. Adapun pelaksanaan pembelajaran tematik dijelaskan dalam paragraf berikut "Pelaksanaan pembelajaran Tematik Terpadu berawal dari tema yang telah dipilih/dikembangkan oleh guru yang sesuai dengan kebutuhan peserta didik. Jika dibandingkan dengan pembelajaran konvensional pembelajaran tematik ini tampak lebih menekankan pada Tema sebagai pemersatu berbagai mata pelajaran yang lebih diutamakan pada makna belajar, dan keterkaitan berbagai konsep mata pelajaran. Keterlibatan peserta didik dalam belajar lebih diprioritaskan dan pembelajaran yang bertujuan mengaktifkan peserta didik, memberikan pengalaman langsung serta tidak tampak adanya pemisahan antar mata pelajaran satu dengan lainnya."

Untuk menerapkan pembelajaran ini, tentu diperlukan pendidik yang benar-benar menguasai bidang keilmuan secara kritis dan komperehensif.

5. Pendidik

Pendidik dalam Islam dimaknai sebagai orang-orang yang bertanggung jawab terhadap perkembangan anak didik dengan mengupayakan perkembangan seluruh potensi anak didik, baik potensi afektif, kognitif, maupun psikomotorik. Sayangnya, menurut Rahman, pendidik yang berkualitas sangat sulit ditemukan di lembaga-lembaga pendidikan (Fazlur Rahman, 1982: 116). Untuk mengatasi kelangkaan tenaga pendidik seperti itu, Rahman menawarkan beberapa 
gagasan sebagai berikut (Rahman, 1982: 142-148):

a. Merekrut dan mempersiapkan anak didik yang memiliki bakat-bakat terbaik dan mempunyai komitmen tinggi terhadap lapangan agama Islam.

b. Meningkatkan lulusan madrasah yang relatif cerdas atau menunjuk para doktor lulusan Barat menjadi guru besar pada bidang studi Bahasa Arab, Bahasa Persi, dan Sejarah Islam.

c. Para pendidik harus dilatih di pusat pusat studi Islam di luar negeri, khususnya Barat. Hal ini pernah dilakukan Rahman sewaktu ia menjabat direktur Institut Pusat Penelitian Islam di Pakistan.

d. Melatih lulusan madrasah yang memiliki kemampuan bahasa Arab dengan riset modern serta menarik lulusan bidang filsafat dan ilmuilmu sosial untuk dilatih bahasa Arab dan disiplin Islam klasik.

e. Menggiatkan para pendidik untuk melahirkan karya-karya keislaman secara kreatif dan memiliki tujuan

Sejalan dengan yang dikemukakan Fazlur Rahman, UndangUndang No. 14 Tahun 2005 mendefinisikan bahwa guru adalah pendidik profesional dengan tugas utama mendidik, mengajar, membimbing, mengarahkan, melatih, menilai, dan mengevaluasi peserta didik pada pendidikan anak usia dini jalur pendidikan formal, pendidikan dasar, dan pendidikan menengah.

Berdasarkan definisi di atas, dapat kita garis bawahi bahwa seorang pendidik memiliki tugas utama mendidik, mengajar, membimbing, mengarahkan, melatih, menilai hingga melakukan evaluasi peserta didik. Seorang pendidik tidak hanya mentransfer ilmu pengetahuan saja, tetapi juga mentransfer nilai-nilai, etika dan moral yang baik. Sebagai seorang murabbi ruh, pendidik juga bertugas melakukan bimbingan dan pelatihan, baik dalam kegiatan kelas maupun kegiatan di luar kelas. Pendidik harus siap mendengarkan permasalahan yang dialami peserta didik serta menawarkan berbagai solusi untuk menyelesaikannya. Pendidik juga harus mengarahkan peserta didik untuk mengembangkan minat dan bakatnya. Selain itu, pendidik harus melakukan penilaian dan evaluasi untuk melihat kemajuan yang dialami oleh peserta didik. Oleh karena itu, seorang guru dituntut memiliki kompetensi pedagogik, sosial, kepribadian, profesional, dan leadership. Berdasarkan uraian tersebut, dapat kita definisikan kembali bahwa secara umum, pendidik merupakan orang yang memiliki tanggung jawab terhadap perkembangan peserta didik, baik perkembangan dalam aspek kognitif, afektif, maupun psikomotorik.

Definisi pendidik menurut Fazlur Rahman juga senada dengan definisi pendidik dalam buku "Ilmu Pendidikan Islam" yang ditulis oleh Muhammad Muntahibun Nafis. Buku tersebut menjelaskan bahwa pendidik dalam pendidikan Islam pada hakikatnya adalah orang-orang yang bertanggung jawab terhadap perkembangan peserta didik dengan mengupayakan seluruh potensi dan kecenderungan yang ada pada peserta didik, baik yang mencakup ranah afektif, kognitif, maupun psikomotorik (Nafiz, 2011: 85). Maka kemudian kita dapat 
menemukan relevansi antara pemikiran Fazlur Rahman dengan konsep pendidik untuk saat ini.

Seperti yang diungkapkan Fazlur Rahman, pendidik dengan kriteria seperti itu tidak banyak ditemukan di lapangan karena pada praktiknya kita sering menjumpai pendidik yang tidak memenuhi kualifikasi dan kompetensi yang ditentukan. Menanggapi hal tersebut, sebenarnya pemerintah telah mengeluarkan peraturan dan kebijakan melalui undang-undang, di antaranya dalam UU No. 14 Tahun 2005 Tentang Guru dan Dosen Pasal 34 Ayat 1 yaitu "Pemerintah dan pemerintah daerah wajib membina dan mengembangkan kualifikasi akademik dan kompetensi guru pada satuan pendidikan yang diselenggarakan oleh Pemerintah, pemerintah daerah, dan/atau masyarakat."

Salah satu langkah yang ditempuh oleh pemerintah untuk mengembangkan kualifikasi akademik dan kompetensi guru adalah sertifikasi. Sertifikasi merupakan proses pemberian sertifikat untuk pendidik. Sertifikat diperoleh melalui beberapa syarat tertentu. Selain itu, pendidik juga digiatkan untuk membuat berbagai tulisan serta melakukan riset dengan menerbitkan jurnal, mengingat negara kita cukup tertinggal dalam masalah ini. Pendidik atau calon pendidik yang berprestasi juga diberi kesempatan melanjutkan studinya dengan beasiswa. Adapun terkait pelatihan, pendidik diperkenankan mengikuti berbagai pelatihan dan seminar, seperti pelatihan Kurikulum 2013 dan lain-lain. Dengan demikian, usaha Fazlur Rahman dalam upaya peningkatan kualitas pendidik relevan dengan usaha yang dilakukan pemerintah. Justru usaha Rahman dapat dijadikan sebagai model yang nantinya dapat diterapkan oleh pemerintah Indonesia untuk semakin meningkatkan kualitas pendidik secara lebih komperehensif.

6. Metode Pendidikan Islam

Metode yang menghasilkan alumni yang kritis dan kreatif adalah metode a double movement. Metode ini awalnya digunakan untuk memahami dan menafsirkan al-Qur'an. Metode ini terdiri dari dua gerakan ganda, yaitu membawa situasi sekarang ke masa alQur'an diturunkan dan kembali lagi ke masa kini. (Rahman, 1982: 7-9). Selanjutnya, gerakan ini diterjemahkan sebagai metode pendidikan antara guru dan murid dalam sebuah pembelajaran.

Metode ini terdiri dari gerakan ganda, yaitu gerakan dari guru ke murid dan gerakan dari murid ke guru. Kalau perlu ada juga gerakan di antara sesama murid. Dengan metode ini, diharapkan siswa memiliki keleluasan dalam melakukan berbagai aktivitas sehingga mereka tidak hanya mendengarkan ceramah dari guru, tetapi juga membaca, memahami, menganalisis, menulis, mengadakan eksperimen, mengalami proses pembuktian, sampai penemuan (Sutrisno, 2005: 186-187). Metode lain yang tidak kalah penting adalah metode diskusi, metode pembelajaran kebebasan, dan penyadaran. Subjek didik disadarkan akan posisinya, lantas diberi kebebasan dan motivasi untuk berbuat (Sutrisno, 2005: 189). 
Salinan Permendikbud No. 65 Tahun 2013 tentang standar proses menyatakan bahwa "Kegiatan inti menggunakan model pembelajaran, metode pembelajaran, media pembelajaran, dan sumber belajar yang disesuaikan dengan karakteristik peserta didik dan mata pelajaran. Pemilihan pendekatan tematik dan/atau tematik terpadu dan/atau saintifik dan/atau inkuiri dan penyingkapan (discovery) dan/atau pembelajaran yang menghasilkan karya berbasis pemecahan masalah (project based learning) disesuaikan dengan karakteristik kompetensi dan jenjang pendidikan."

Proses pembelajaran pada Kurikulum 2013 tidak lagi berpusat pada guru, tetapi berpusat pada siswa. Hal ini bukan berarti guru tidak memiliki peran. Guru menjadi fasilitator yang bertugas mengatur jalannya pembelajaran di kelas, sehingga baik guru maupun siswa sama-sama memiliki peran aktif dalam menciptakan pembelajaran yang menyenangkan. Guru tidak melulu menyampaikan materi dengan metode ceramah, tetapi juga dengan diskusi, tanya jawab, dan sebagainya. Bahkan masih ada puluhan strategi yang bisa diterapkan. Selain itu, proses pembelajaran yang pada mulanya berupa eksplorasi, elaborasi, dan konfirmasi (EEK), pada Kurikulum 2013 ini dikembangkan menjadi mengamati, menanya, mencoba, menalar, dan menyajikan (5M). Di sini, metode double movement Fazlur Rahman relevan dengan metode yang diterapkan dalam Kurikulum 2013.

7. Sarana Pendidikan
Sarana pendidikan berupa gedung, perpustakaan serta lainnya sangatlah erat hubungannya dengan mutu sekolah. Rahman dalam hal ini menyadari betapa pentingnya alat-alat dan sarana tersebut bagi peningkatan mutu pendidikan. Hal ini ia perhatikan dari berdirinya lembaga-lembaga ilmu pengetahuan yang berdiri pada abad klasik, terutama saat dinasti-dinasti berdiri (Rahman, 1994: 265-267).

Berbicara sarana pendidikan sama halnya dengan bicara dana pendidikan. Adanya sarana diperoleh dari dana yang dimiliki oleh sebuah lembaga pendidikan. Sarana pendidikan sebagaimana dikemukakan oleh Fazlur Rahman memiliki relevansi dengan pendidikan di Indonesia saat ini.

Selanjutnya menurut Rahman, perpustakaan di lembaga-lembaga pendidikan Islam masih belum memadai, terutama jumlah buku-buku yang berbahasa Arab dan Inggris. Untuk mengatasi hal tersebut, Rahman mengusulkan agar fasilitas perpustakaan harus dilengkapi dengan buku-buku yang berbahasa Arab dan Inggris (Iqbal, 2015: 625). Buku merupakan jendela dunia. Ibarat sebuah rumah akan gelap tanpa adanya jendela. Dengan buku, seseorang mampu melihat cakrawala keilmuan yang lebih luas, bahkan semakin banyak jendela yang dibuka, semakin banyak informasi yang akan kita dapatkan.

Bahasa Inggris dan Bahasa Arab merupakan bahasa internasional. Keduanya dituntut untuk dikuasai oleh setiap peserta didik terutama dalam menghadapi persaingan global. Untuk mewujudkannya, setiap lembaga 
pendidikan di Indonesia menyelenggarakan pembelajaran bahasa Inggris dan bahasa Arab serta melengkapi literatur di perpustakaan dengan kedua bahasa tersebut. Pentingnya kedua bahasa tersebut menjadikan lembaga pendidikan non formal turut menyelenggarakan pembelajaran bahasa asing untuk menunjang kemampuan bahasa peserta didik. Bahkan pesantren sebagai lembaga pendidikan Islam juga telah banyak yang memfokuskan kajian terhadap kedua bahasa tersebut.

Literatur atau buku-buku yang menggunakan bahasa Inggris dan Arab pada pendidikan formal dapat kita jumpai di level terbawah, seperti PAUD dan TK. Ketersediaan bukubuku tersebut masih berlanjut hingga perguruan tinggi. Dengan demikian, pemikiran Fazlur Rahman mengenai sarana pendidikan memiliki relevansi dengan sarana pendidikan di Indonesia yang sama-sama masih menunjukkan adanya kekurangan sehingga diperlukan adanya tambahan.

\section{PENUTUP}

Fazlur Rahman dilahirkan dalam keluarga yang taat beragama. Ketekunan dan kedisiplinan ayahnya serta pendidikan moral yang diberikan ibunya sangat mempengaruhi dalam pemikiran keagamaannya sehingga Rahman mampu menghadapi berbagai macam peradaban dan tantangan di alam modern.

Pendidikan dasar ia dapatkan dari keluarga kemudian ia mulai mengeyam pendidikan formal mulai pendidikan menengah. Rahman menyelesaikan pendidikan menengah sampai magister di tanah kelahirannya, hingga ia merasa belum puas atas pendidikannya selanjutnya ia mengambil program doktoral di oxford university. Setelah selesai studi ia mengembangkan berbagai lembaga riset yang memadukan antara pengetahuan umu dan agama sehingga terintegrasi menjadi satu kesatuan yang utuh. Harapannya adalah membentuk pribadi yang kuat beragama sekaligus memiliki kecakapan dalam bidang-bidang umum dan modern.

Setelah dilakukan analisis bahwasannya pemikiran Fazlur Rahman relevan dengan pendidikan di Indonesia dilihat dari dasar pendidikan, pengertian pendidikan Islam, tujuan pendidikan, peserta didik, pendidik, metode pendidikan Islam, dan sarana pendidikan.[] 


\section{DAFTAR RUJUKAN}

Arikunto, Suharsimi. Prosedur Penelitian suatu pendekatan Praktek, Jakarta: PT. Rineka Cipta, 1998.

Assegaf, Abd. Rahman. Aliran Pemikiran Pendidikan Islam, Jakarta: Raja Grafindo Persada, 2013.

Fahmi. "Pendidikan Islam Perspektif Fazlur Rahman" dalam Jurnal Pendidikan Agama Islam, Vol. II, No. 2, 2016.

Ikhtiono, Gunawan. Pendidikan Nondikotomik Fazlur Rahman, Yogyakarta, Kaukaba, 2014.

Iqbal, Abu Muhammad. Pemikiran Pendidikan Islam, Yogyakarta: Pustaka Pelajar, 2015.

Khotimah. "Pemikiran Fazlur Rahman Tentang Pendidikan Islam" dalam Jurnal Ushuluddin, Vol. XXII, No. 2, Juli: 2014.

Mustafa. "Pemikiran Pendidikan Fazlur Rahman", dalam Jurna Pendidikan Islam Iqra', Vol. VI, No. 1, 2018.

Nafiz, Muhammad Muntahibun. Ilmu Pendidikan Islam, Yogyakarta: Teras, 2011.

Nata, Abuddin. Pemikiran Pendidikan Islam dan Barat, Jakarta: Rajawali Press, 2013.

Permendikbud No. 65 Tahun 2013 Tentang Standar Proses.

Rahman, Fazlur. "Islamization of knowledge: A Response", dalam The American Journal of Islamic Social Science, Vol. 5, No. 1, 1988.

Rahman, Fazlur. "An Autobiographical Note" dalam Journal of Islamic Research, Vol. 4, No. 2, Oktober: 1990.

Rahman, Fazlur. "The Qur'anic Solution of Pakistan's Educational Problems", "Islamic Studies", Vol. 6, No. 4, 1967.

Rahman, Fazlur. Islam and Modernity: Transformation of an Intellectual
Tradition, London: University of Chicago Press. 1982.

Saintifik Tematik Terpadu SD / MI HO. 2. 2-2.

Sanjaya, Wina. Penelitian Pendidikan: Jenis, Metode, dan Prosedur, Jakarta: Kencana, 2013.

Sibawaihi. "Implikasi Pemikiran Ketuhanan Fazlur Rahman terhadap Pendidikan Islam", dalam Usman, (ed.), Pendidikan Islam: konsep, Aksi, dan evaluasi, Yogyakarta: Fakultas Ilmu Tarbiyah dan Keguruan, 2010.

Sugiyono. Metode Penelitian Manajemen, Bandung: Alfabeta, 2013.

Surakhmad, Winarno. Pengantar Penelitian Ilmiah, Bandung: 1992.

Sutrisno. Fazlur Rahman: kajian terhadap metode, epistemologi, dan sistem pendidikan, Yogyakarta: Pustaka Pelajar, 2005.

Tim Penyusun. Undang-Undang Nomor 20 Tahun 2003 tentang Sisdiknas, Bandung: Citra Umbara, 2012.

Undang-Undang Republik Indonesia Nomor 14 Tahun 2005 tentang Guru. 